\title{
Investigation of Outdoor/Indoor Air Quality During the Outbreak of COVID-19: A Review Study
}

\author{
Abdolmajid Fadaei ${ }^{1 *}$ (i) \\ ${ }^{1}$ Department of Environmental Health Engineering, School of Health, Shahrekord University of Medical Sciences, Shahrekord, IRAN \\ *Corresponding Author: ali2fadae@yahoo.com
}

Citation: Fadaei, A. (2022). Investigation of Outdoor/Indoor Air Quality During the Outbreak of COVID-19: A Review Study. European Journal of Sustainable Development Research, 6(1), em0180. https://doi.org/10.21601/ejosdr/11726

\section{ARTICLE INFO}

Received: 26 Oct. 2021

Accepted: 31 Jan. 2022

\begin{abstract}
The 2019 novel coronavirus (COVID-19) pandemic has enormously affected the world and become a worldwide problem. To control the spread of COVID-19, human behaviors are generally controlled in most countries. However, exposure to air pollution causes increased susceptibility to COVID-19. The goal of this review research was to investigate the outdoor/indoor air quality during the outbreak of COVID-19. A review search was carried out from the databases Scopus, PubMed, Web of Knowledge, and Embase using the key words: "air quality" and "COVID-19 pandemic". Twenty-four released articles were ultimately identified as eligible candidates for review study. The type of environment, country and city, type of study, goal of study, and study findings were analyzed. The results demonstrated the significant relationship between air pollution $\left(\mathrm{PM}_{2.5}, \mathrm{PM}_{10}, \mathrm{SO}_{2}, \mathrm{NO}_{2}, \mathrm{CO}\right.$, and $\left.\mathrm{O}_{3}\right)$ and the COVID-19 event. Indoor pollutant concentrations were typically higher during COVID-19 lockdown. There is also a relationship between meteorological parameters (rainfall, relative humidity, temperature, wind speed, and sunlight) and COVID-19 spread. The air quality index (AQI) of most countries improved to varying grades of quality under the COVID-19 infection control. It is crucial that policy makers and decision makers adopt more valuable methods to assist betterment of air pollution, particularly in developing nations, or control contact with pollutants so as to preserve public wellbeing.
\end{abstract}

Keywords: air pollution, meteorological, COVID-19 infection, SARS-CoV-2, lockdown

\section{INTRODUCTION}

Coronavirus is one of the most important pathogens that affect a person's respiratory system. The Coronavirus infection 2019 (COVID-19) is caused by a new CoV-2, called severe acute respiratory syndrome coronavirus (SARS-CoV-2), which was previously identified as 2019 novel coronavirus (2019-nCoV) (Li et al., 2020). SARS-CoV-2 is spread from person to person through close communication, as well as via respiratory droplets greater than $5 \mu \mathrm{m}$ in diameter, which are produced when a sick person coughs, sneezes, speaks, or sings at close distances, typically less than 1-2m (Chirico et al., 2020). The airborne diffusion of droplet nuclei particles smaller than $5 \mu \mathrm{m}$ in diameter is considered as an important cause of infection (Correia et al., 2020; Sadeghi et al., 2020). Transmission dynamics of COVID-19 is governed by several systemic causes, including normal factors (i.e., biological specifications of virus, latency time, etc.), particular factors (e.g., complex interaction between air quality, climatic conditions, and biological specifications of viral infection), and wellbeing level of individuals (lifestyle, immune system, age, gender, etc.) (Ahmadi and Fadaei 2021; Coccia, 2020). There is an inextricable connection between meteorological variables and air pollutants (Hou and $\mathrm{Xu}, 2022$ ). Major air pollutants include particulate matter with diameters less than or equal to $10 \mu \mathrm{m}$ $\left(\mathrm{PM}_{10}\right)$; or $2.5 \mu \mathrm{m}$ or less $\left(\mathrm{PM}_{2.5}\right)$, nitrogen dioxide $\left(\mathrm{NO}_{2}\right)$, carbon monoxide (CO), black carbon (BC), sulfur dioxide $\left(\mathrm{SO}_{2}\right)$, volatile organic compounds (VOCs), ozone $\left(\mathrm{O}_{3}\right)$. Aerosol optical depth (AOD) levels and meteorological factors (wind rate, wind direction, temperature, relative humidity, and sunlight under the movement control order [MCO]) are among meteorological variables (Coccia, 2021; Rosario et al., 2020) affecting air quality. The air quality condition is explained on the basis of the pollutant standard index (PSI), air quality index (AQI), air quality health index (AQHI), and air pollutant index (API) of 5 or 6 key parameters. Additionally, $\mathrm{CO}_{2}$ is generally recommended as the key indoor pollutant indicator and the index of the forcefulness of ventilation and the regeneration capability of the indoor environment (Fernández-Agüera et al., 2019). Every specification of the socio-economic and health effects of COVID-19 must be understood to control it. Many researchers have demonstrated that the prevalence of these infections can also be due to longterm exposure to atmospheric pollution, particularly nitrogen dioxide $\left(\mathrm{NO}_{2}\right)$, and particle matter with diameters of $2.5 \mu \mathrm{m}$ 
$\left(\mathrm{PM}_{2.5}\right)$ entering the air because of human-made actions (mostly fossil fuel burning from motor vehicles, traffic, transport and the combustion of fuels for industrial facilities, commercial and household applies and power stations) and natural processes (lightning, crystal dust, dust storms, and soil reactions). High exposure to pollutants is associated with hypertension, heart and cardiovascular diseases, asthma, bronchiolitis and also lung cancer, central nervous system functional disorders, cutaneous diseases, elevated rate of hospitalization, chronic obstructive pulmonary disease (COPD), considerable deficiencies in growth of lung function in children, poor lung role in adolescents or lung damage, and diabetes (Farhadi et al., 2020; Gan et al., 2012; Ogen, 2020; Shin et al., 2020). Additionally, air pollution may affect mental health, conception, fertility, and defensive cost (He et al., 2020; Ito and Zhang, 2020). Air pollution also imposes economic burden on public and healthcare providers (Farhadi et al., 2020). There are a few research studies on indoor air pollution during the outbreak of COVID-19. Therefore, this event has caused most nations to announce stay-at-home orders as a protective measure to be taken to prevent the release of the virus. Therefore, the main human-made resources of emissions in urban regions, particularly in the transport sector, have considerably decreased with these quarantine periods (Dong et al., 2019; Navinya et al., 2020). In this research, the levels of six main air pollutants $\left(\mathrm{PM}_{10}, \mathrm{PM}_{2.5}\right.$, $\mathrm{SO}_{2}, \mathrm{NO}_{2}, \mathrm{O}_{3}$, and $\mathrm{CO}$ ), which have been evaluated in eight countries worldwide under COVID-19, are investigated. This fast literature review tries to provide adequate knowledge and strategies for improving outdoor and indoor air quality during a pandemic or crisis. Thus, in this study, the researcher evaluated the outdoor/indoor air quality during the outbreak of COVID-19.

\section{METHODS}

In the present study, a multidisciplinary reviewing framework was used to search articles on air pollution. To achieve this goal, the databases were systematically searched using various combinations of the following 34 keywords: "airpollution OR air quality”, "air-pollution AND COVID-19”, "COVID-19 AND indoor pollution", "indoor air quality AND COVID-19”, "Movement control order AND air pollution”, "Movement control order AND COVID-19", "Change of air quality AND COVID-19”, "outdoor air quality AND COVID19”, “PM 2.5 AND COVID-19 infection”, “Covid-19 Lockdown AND Air Quality Index", and "Covid-19 Lockdown AND climate parameters". Articles on COVID-19 lockdown and the air pollution-related indicators were reviewed. Moreover, references of the identified articles were also reviewed to increase the comprehensiveness of the search. After all entitlements/abstracts were separately reviewed to recognize the possible related articles, the author selected research studies for full article review.

The identified articles were found eligible after evaluating against inclusion criteria, objectives, and recommended indicators. The inclusion criteria were: access to the original article, English language, and investigating the outdoor/indoor air quality during the outbreak of the COVID-

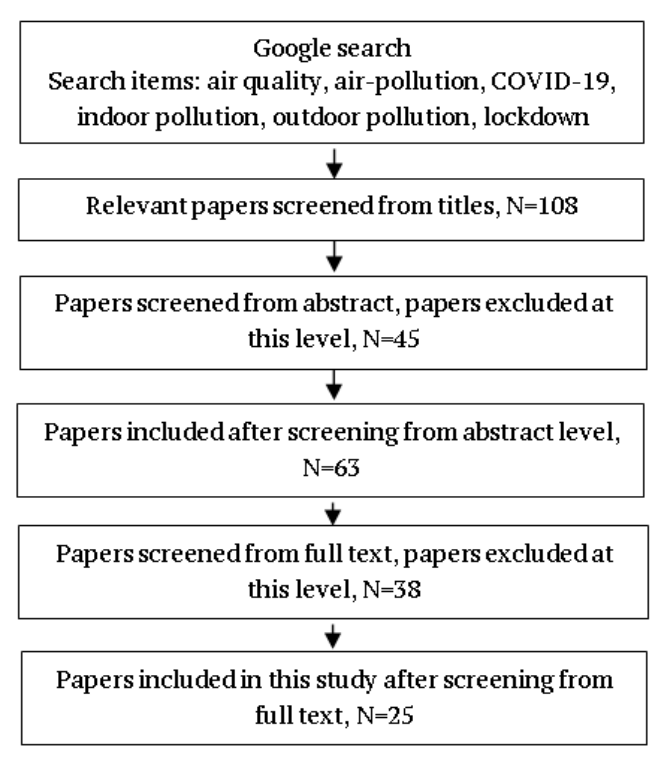

Figure 1. Chart< presentation of the review process

19 pandemic. The exclusion criteria were no access to the fulltext article, review studies, book reviews, guidelines, protocols, letters-to-editors, articles submitted to conferences, theses, white papers, etc. As shown in Figure 1, 108 peer reviewed publications were accessed based on the relevance of titles to the research. These articles were further screened to 63 after reading through their abstracts. Following full text screening of the articles, 25 of them were used for this review, excluding the Preferred Reporting Items for Systematic Reviews and Meta-Analyses (PRISMA) reference (Moher et al., 2010). Data related to the name of author(s), country of implementation, objectives, study findings, type of environment, and main variables/parameters, such as $\mathrm{PM}_{10}$, $\mathrm{PM}_{2.5}, \mathrm{CO}, \mathrm{NO}_{2}, \mathrm{SO}_{2}, \mathrm{VOC}_{\mathrm{s}}, \mathrm{O}_{3}, \mathrm{AOD}$, and $\mathrm{AQI}$ and outcomes were collected. The method used for for review was based on (1) outdoor air pollutants during COVID-19 pandemic, (2) effects of meteorological items and COVID-19 outbreak, and (3) indoor air pollutants under COVID-19 outbreak.

\section{FINDINGS}

The main results are provided in Table 1 . Of all identified studies, 17 were observational research on air pollution and COVID-19 pandemic during lockdown. These articles were from China (9), the USA (1), Spain (2), Italy (3), India (3), Malaysia (4), Singapore (1), and Brazil (2). Out of 25 articles studied in this systematic review, 6 (24\%) and19 (76\%) studies were mathematical and observational, respectively (Figure 2). Twenty-two, 1, and 3 studies were concerned with the association between the outdoor and indoor air pollution and COVID-19, and meteorological parameters and COVID-19, respectively. This research found that the mean level of $\mathrm{PM}_{10}$, $\mathrm{PM}_{2.5}, \mathrm{CO}, \mathrm{NO}_{2}, \mathrm{SO}_{2}$, and $\mathrm{VOC}_{s}$ reduced and air quality index improved in about $68 \%$ of reported research studies, and only in $20 \%$ of research studies, $\mathrm{O}_{3}$ concentrations increased during COVID-19 pandemic. In the discussion section, the most important findings are discussed in three parts, including the outdoor air pollutants during the COVID-19 outbreak, effects of meteorological items and COVID-19 outbreak, and indoor air pollutants during the COVID-19 outbreak. 
Table 1. Most important specifications of reviewed articles

\begin{tabular}{|c|c|c|c|c|c|}
\hline $\begin{array}{c}\text { Type of } \\
\text { environment }\end{array}$ & Country & Type of study & Goal of study & Findings \& recommendations & References \\
\hline Indoor & $\begin{array}{l}\text { Spain } \\
\text { (Madrid) }\end{array}$ & Observational & $\begin{array}{l}\text { Survey of air quality in residences } \\
\text { in Madrid before \& during } \\
\text { outbreak of COVID-19 pandemic }\end{array}$ & $\begin{array}{l}\text { Daily mean concentration of } \mathrm{PM}_{2.5}, \mathrm{NO}_{2}, \& \\
\text { VOC } \text { increased by } 12 \%, 37 \%, \& 559 \%, \\
\text { respectively under COVID-19 pandemic } \\
\end{array}$ & $\begin{array}{l}\text { Domínguez- } \\
\text { Amarillo et al. } \\
\text { (2020) }\end{array}$ \\
\hline Outdoor & USA & Observational & $\begin{array}{c}\text { Survey of } \\
\text { air quality \& COVID-19 mortality } \\
\text { in USA } \\
\end{array}$ & $\begin{array}{c}\text { A statistically considerable increase in } \mathrm{PM}_{2.5} \\
\text { may increase susceptibility of infection \& } \\
\text { mortality from COVID-19 }\end{array}$ & $\begin{array}{l}\text { Wu et al. } \\
(2020 b)\end{array}$ \\
\hline Outdoor & Italy & Observational & $\begin{array}{l}\text { Relationship between air quality } \\
\text { \& wind speed }\end{array}$ & $\begin{array}{l}\text { High wind speed has lower numbers of COVID- } \\
19 \text { cases }\end{array}$ & Coccia (2021) \\
\hline Outdoor & Italy & Observational & $\begin{array}{c}\text { Association } \\
\text { between factors (air pollution, } \\
\text { climatic, \& biological } \\
\text { characteristics } \\
\text { of virus) \& COVID-19 } \\
\text { transmission }\end{array}$ & $\begin{array}{l}\text { Mechanisms of COVID-19 outbreak: air } \\
\text { pollution- to-person transmission \& person- } \\
\text { to-person transmission }\end{array}$ & Coccia (2020) \\
\hline Outdoor & Brazil & Observational & $\begin{array}{l}\text { Association between weather } \\
\text { factors (temperature, humidity, } \\
\text { sunlight, wind speed, \& } \\
\text { precipitation) \& COVID-19 }\end{array}$ & $\begin{array}{l}\text { Climatic factors like humidity, temperature, } \\
\text { solar irradiation, \& wind speed have negative } \\
\text { correlation with COVID-19 }\end{array}$ & $\begin{array}{l}\text { Rosario et al. } \\
\qquad(2020)\end{array}$ \\
\hline Outdoor & China & Mathematical & $\begin{array}{l}\text { Air pollution in China during } \\
\text { outbreak of COVID-19 pandemic }\end{array}$ & $\begin{array}{l}\text { Major air pollutants that were considerably } \\
\text { reduced include: } \mathrm{AQI} \text { by } 20.56, \mathrm{PM}_{2.5} \text { by } \\
19.01 \%, \mathrm{PM}_{10} \text { by } 20.20 \%, \& \mathrm{NO}_{2} \text { by } 2.13 \%\end{array}$ & $\begin{array}{l}\text { Song et al. } \\
\text { (2021) }\end{array}$ \\
\hline Outdoor & $\begin{array}{l}\text { China } \\
\text { (Beijing- } \\
\text { Tianjin } \\
\text { Hebei) }\end{array}$ & Mathematical & $\begin{array}{l}\text { Effects of COVID-19 quarantine } \\
\text { on air quality }\end{array}$ & $\begin{array}{c}\text { Quarantine had a considerable affirmative } \\
\text { impact on air quality: AQI (15.2\%), } \mathrm{NO}_{2} \\
(37.8 \%), \mathrm{PM}_{10}(33.6 \%), \mathrm{PM}_{2.5}(21.5 \%), \& \mathrm{CO} \\
(20.4 \%)\end{array}$ & $\begin{array}{l}\text { Wang et al. } \\
\qquad(2021)\end{array}$ \\
\hline Outdoor & China & Mathematical & $\begin{array}{l}\text { Effects of COVID-19 quarantine } \\
\text { on air quality } \\
\end{array}$ & $\begin{array}{l}\text { The quarantine measures decreased AQI by } \\
19.84 \& \mathrm{PM}_{2.5} \text { by } 14.07 \%\end{array}$ & He et al. (2020) \\
\hline Outdoor & China & Mathematical & $\begin{array}{l}\text { Does lockdown decrease air } \\
\text { pollution? }\end{array}$ & $\begin{array}{c}\text { Significantly reduced factors include AQI } \\
(7.80 \%), \mathrm{SO}_{2}(6.76 \%), \mathrm{PM}_{2.5}:(5.93 \%) \\
\mathrm{PM}_{10}(13.66 \%), \mathrm{NO}_{2}(24.67 \%), \& \mathrm{CO}(4.58 \%)\end{array}$ & $\begin{array}{l}\text { Bao and Zhang } \\
\text { (2020) }\end{array}$ \\
\hline Outdoor & India & Mathematical & $\begin{array}{l}\text { Evaluation of ecological effect of } \\
\text { quarantine }\end{array}$ & $\begin{array}{l}\text { Reduction of } 85.1 \% \text { in } \mathrm{PM}_{2.5}, \mathrm{PM}_{10}, \& \mathrm{NO}_{2} ; \mathrm{CO} \\
\text { has also reduced significantly, which is finding } \\
\text { of constrained personal actions }\end{array}$ & $\begin{array}{c}\text { Lokhandwala } \\
\text { and Gautam } \\
(2020)\end{array}$ \\
\hline Outdoor & $\begin{array}{c}\text { Spain } \\
\text { (Barcelona) }\end{array}$ & Observational & $\begin{array}{l}\text { Revolutions in air quality during } \\
\text { outbreak of COVID-19 pandemic }\end{array}$ & $\begin{array}{l}\text { Black carbon \& } \mathrm{NO}_{2} \text { concentrations decreased } \\
\text { by } 50 \% \text { during quarantine phase; } \mathrm{PM}_{10} \text { reduced } \\
\text { but at a much lesser level, reducing agents are } \\
\text { still unrevealed; } \mathrm{O}_{3} \text { levels raised by about } 50 \% \text {. }\end{array}$ & $\begin{array}{l}\text { Tobías et al. } \\
\text { (2020) }\end{array}$ \\
\hline Outdoor & $\begin{array}{l}\text { Brazil (Rio } \\
\text { de Janeiro) }\end{array}$ & Observational & $\begin{array}{l}\text { Effect of COVID-19 quarantine on } \\
\text { air quality }\end{array}$ & $\begin{array}{c}\mathrm{PM}_{10}, \mathrm{NO}_{2}, \& \mathrm{CO} \text { levels decreased \& } \mathrm{O}_{3} \text { levels } \\
\text { increased during COVID-19 pandemic }\end{array}$ & $\begin{array}{l}\text { Dantas et al. } \\
(2020)\end{array}$ \\
\hline Outdoor & $\begin{array}{l}\text { Malaysia } \\
\text { (Klang } \\
\text { Valley) }\end{array}$ & Mathematical & $\begin{array}{l}\text { Air pollutants during COVID-19 } \\
\text { pandemic }\end{array}$ & $\begin{array}{c}\mathrm{NO}, \mathrm{NO}_{2}, \& \mathrm{CO} \text { reduced by } 77.30 \%, 55.30 \%, \& \\
64.80 \% \text {, respectively; } \mathrm{O}_{3} \text { levels increased by } \\
\text { around 30\% during COVID-19 quarantine } \\
\text { phase }\end{array}$ & $\begin{array}{l}\text { Latif et al. } \\
\qquad(2021)\end{array}$ \\
\hline Outdoor & $\begin{array}{l}\text { India } \\
\text { (Delhi) }\end{array}$ & Observational & $\begin{array}{l}\text { Effect of COVID-19 quarantine } \\
\text { phase on air pollution }\end{array}$ & $\begin{array}{c}\mathrm{NO}_{2}, \mathrm{PM}_{2.5}, \mathrm{PM}_{10}, \& \mathrm{CO} \text { reduced by } 52.68 \% \\
50.00 \%, 50.00 \%, \& 30.35 \% \text {, respectively; air } \\
\text { quality have improved around } 60 \% \text { during } \\
\text { COVID-19 phase }\end{array}$ & $\begin{array}{l}\text { Mahato et al. } \\
\qquad(2020)\end{array}$ \\
\hline Outdoor & Malaysia & Observational & $\begin{array}{l}\text { Effect of COVID-19 on } \\
\text { atmospheric environment }\end{array}$ & $\begin{array}{l}\text { Parameters of air pollution levels decline } \\
\text { during COVID-19 quarantine phase ranged } \\
\text { from } \\
\text { 26-31\%, 23-32\%, 63-64\%, 9-20\%, \& } 25-31 \% \text { in } \\
\text { PM10, PM2.5, NO2, SO2, \& CO, respectively }\end{array}$ & $\begin{array}{l}\text { Kanniah et al. } \\
\text { (2020) }\end{array}$ \\
\hline Outdoor & $\begin{array}{l}\text { China } \\
\text { (Wuhan) }\end{array}$ & Observational & $\begin{array}{l}\text { Effect of COVID-19 quarantine } \\
\text { on air pollution \& health }\end{array}$ & $\begin{array}{l}\text { Two parameters } \mathrm{PM}_{2.5} \& \mathrm{NO}_{2} \text { levels reduced by } \\
35 \% \text { and } 63 \% \text {, respectively during lockdown } \\
\text { period }\end{array}$ & $\begin{array}{l}\text { Cole et al. } \\
\text { (2020) }\end{array}$ \\
\hline Outdoor & Malaysia & Observational & $\begin{array}{l}\text { To evaluate changes of four main } \\
\text { air quality concentrations during } \\
\text { COVID-19 quarantine phase }\end{array}$ & $\begin{array}{c}\text { Mean levels of factors } \mathrm{CO}, \mathrm{PM}_{2.5}, \& \mathrm{NO}_{2} \\
\text { reduced by } 21.74 \%, 23.1 \%, \& \\
54.0 \% \text {, respectively, whilst that of } \mathrm{SO}_{2} \text { was } \\
\text { invariable } \\
\end{array}$ & $\begin{array}{l}\text { Ash'aari et al. } \\
\qquad(2020)\end{array}$ \\
\hline Outdoor & $\begin{array}{c}\text { China } \\
\text { (East China) }\end{array}$ & Observational & $\begin{array}{l}\text { Assessing COVID-19 impact on } \\
\text { changes of air pollution }\end{array}$ & $\begin{array}{c}\text { Values of CO \& } \mathrm{NO}_{2} \text { reduced by } 20 \% \& 30 \% \& \\
\text { this led to better air quality in short period } \\
\text { during COVID-19 quarantine }\end{array}$ & $\begin{array}{l}\text { Filonchyk and } \\
\text { Peterson } \\
(2020) \\
\end{array}$ \\
\hline
\end{tabular}


Table 1 (Continued). Most important specifications of reviewed articles

\begin{tabular}{|c|c|c|c|c|c|}
\hline $\begin{array}{c}\text { Type of } \\
\text { environment }\end{array}$ & Country & $\begin{array}{l}\text { Type of } \\
\text { study }\end{array}$ & Goal of study & Findings \& recommendations & References \\
\hline Outdoor & Singapore & Observational & $\begin{array}{l}\text { Variations in air pollution under } \\
\text { COVID-19 pandemic }\end{array}$ & $\begin{array}{l}\text { Values of factors } \mathrm{PM}_{10}, \mathrm{PM}_{2.5}, \mathrm{NO}_{2}, \mathrm{CO}, \mathrm{SO}_{2}, \& \mathrm{PSI} \\
\text { reduced by } 23 \%, 29 \%, 54 \%, 6 \%, 52 \%, \& 19 \% \\
\text { respectively, while that of } \mathrm{O}_{3} \text { increased by } 18 \%\end{array}$ & $\begin{array}{l}\text { Li and } \\
\text { Tartarini } \\
(2020) \\
\end{array}$ \\
\hline Outdoor & Malaysia & Observational & $\begin{array}{c}\text { Air quality during stay-at-home } \\
\text { order }\end{array}$ & $\begin{array}{c}\mathrm{PM}_{2.5} \text { levels reduced by } 58.4 \% \text { under movement } \\
\text { control order (MCO); decline did not only } \\
\text { depend on lockdown }\end{array}$ & $\begin{array}{l}\text { Abdullah et } \\
\text { al. }(2020)\end{array}$ \\
\hline Outdoor & Italy (Milan) & Observational & $\begin{array}{l}\text { Effect of COVID-19 quarantine } \\
\text { phase on air quality pollution }\end{array}$ & $\begin{array}{c}\text { A considerable decline was found in } \\
\text { concentrations of } \mathrm{PM}_{10}, \mathrm{PM}_{2.5} \text {, black carbon, } \mathrm{CO} \text {, } \\
\text { benzene, \& NOx during lockdown }\end{array}$ & $\begin{array}{l}\text { Collivignarel } \\
\text { li et al. } \\
(2020) \\
\end{array}$ \\
\hline Outdoor & India & Observational & $\begin{array}{l}\text { Effects of COVID-19 quarantine on } \\
\text { air quality }\end{array}$ & $\begin{array}{l}\text { Air pollutants, including } \mathrm{PM}_{10}, \mathrm{PM}_{2.5}, \mathrm{NO}_{2}, \& \mathrm{CO} \\
\text { decreased during COVID-19 lockdown by } 71 \% \text {, } \\
68 \%, 63 \%, \& 87 \% \text {, respectively }\end{array}$ & $\begin{array}{l}\text { Navinya et } \\
\text { al. }(2020)\end{array}$ \\
\hline Outdoor & $\begin{array}{c}\text { China } \\
\text { (Mainland) }\end{array}$ & Observational & Effect of COVID-19 on air quality & $\begin{array}{c}\text { Average levels of parameters } \mathrm{PM}_{2.5}, \mathrm{PM}_{10}, \mathrm{SO}_{2} \\
\mathrm{NO}_{2} \text {, \& CO reduced by } 14 \%, 15 \%, 12 \%, 16 \%, \& \\
12 \% \text {, respectively whilst level of } \mathrm{O}_{3} \text { raised by } 9 \%\end{array}$ & $\begin{array}{l}\text { Chen et al. } \\
\qquad(2020)\end{array}$ \\
\hline Outdoor & $\begin{array}{l}\text { China } \\
\text { (Wuhan) }\end{array}$ & Mathematical & $\begin{array}{c}\text { Relationships between climatic } \\
\text { items (temperature \& humidity) \& } \\
\text { death COVID-19 cases } \\
\end{array}$ & $\begin{array}{l}\text { Influence of meteorological (temperature change } \\
\& \text { moisture ) items on COVID-19 fatality }\end{array}$ & $\begin{array}{l}\text { Ma et al. } \\
(2020)\end{array}$ \\
\hline Outdoor & $\begin{array}{l}\text { China }(122 \\
\text { cities })\end{array}$ & Observational & $\begin{array}{l}\text { Association between environment } \\
\text { temperature \& COVID-19 infection }\end{array}$ & $\begin{array}{l}\text { There is a relationship between temperature \& } \\
\text { counts of COVID-19 }\end{array}$ & $\begin{array}{l}\text { Xie and Zhu } \\
(2020)\end{array}$ \\
\hline
\end{tabular}

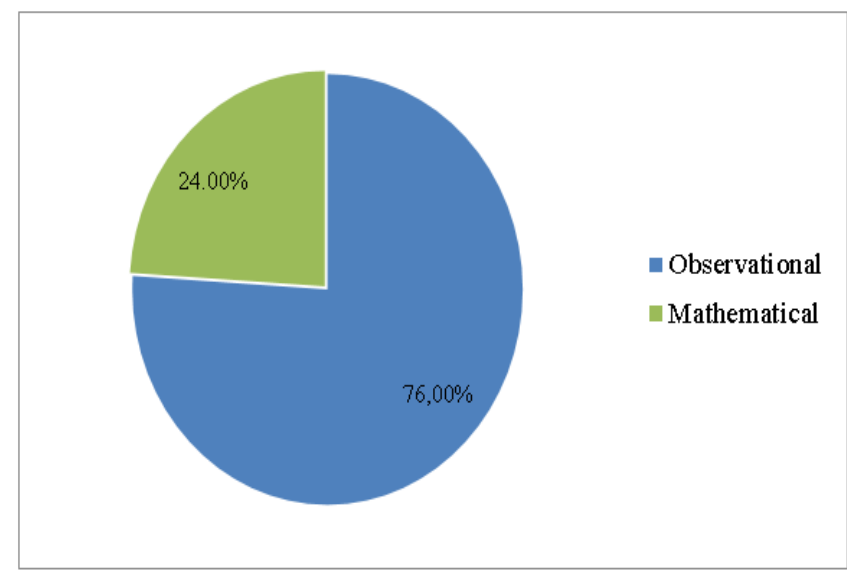

Figure 2. Specification type of design articles

\section{DISCUSSION}

\section{Outdoor Air Pollutants During the COVID-19 Outbreak}

In this study, a comprehensive literature review was conducted concerning the correlation between air pollution and COVID-19 crisis. In total, 25 articles were found to be eligible for a full evaluation. 17 articles were observational and investigated the association between air quality (i.e. effectiveness and key elements) and COVID-19 pandemic. According to the results (Table 1), the emission levels of the pollutants $\mathrm{PM}_{2.5}, \mathrm{PM}_{10}$, and $\mathrm{NO}_{2}$ reduced, whilst the emitted levels of $\mathrm{SO}_{2}, \mathrm{CO}$, and $\mathrm{O}_{3}$ did not decline considerably in the short period. More analysis demonstrated that there was no electricity generation and supply industry turn off, and the corresponding development of the burning and heating period of household stoves may be the cause why the levels of $\mathrm{SO}_{2}$ and $\mathrm{CO}$ did not vary considerably. Moreover, the level of $\mathrm{O}_{3}$ is related to solar irradiation and the levels of NOx, which may indicate the absence of important variations in $\mathrm{O}_{3}$ levels in a short time. The $\mathrm{O}_{3}$, a secondary pollutant, is produced when oxygen in the air is exposed to sunlight and combines with NOx and volatile organic compounds in the air. It takes some time for the level of $\mathrm{O}_{3}$ to change, so no change in $\mathrm{O}_{3}$ was captured in the short term (Song et al., 2021).

Another study by Tobías et al. (2020) reported that the $\mathrm{O}_{3}$ levels noticeably raised in the town as an outcome of three agents, including first, the reduction of NOx in a VOCrestricted environment that causes the $\mathrm{O}_{3}$ level in town to raise; second, the reduction of NO that decreases consumption of $\mathrm{O}_{3}$ and causes an increase in the $\mathrm{O}_{3}$ levels; and third, the usual increase of the exposure to the sun's rays and temperature during many seasons of the year. Briz-Redón et al. (2021) stated that there is a considerable association between air quality and the incidence of the COVID-19. Short time contact to greater levels of five parameters $\mathrm{PM}_{10}, \mathrm{PM}_{2.5}$, $\mathrm{CO}, \mathrm{O}_{3}$, and $\mathrm{NO}_{2}$ is linked to a raised chance of getting sick from COVID-19.

Another study by Brandt et al. (2020) reported that a positive relationship was observed between outcome pollution measures from the air pollution index $\left(\mathrm{CO}, \mathrm{NO}_{2}, \mathrm{SO}_{2}, \mathrm{O}_{3}\right.$, and $\mathrm{PM}_{10}$ ) and COVID-19 case-mortality rates. Conticini et al. (2020) illustrated the possible association between pollution and the development of acute respiratory distress syndrome (ARDS), and eventually, death.

Tian et al. (2021) demonstrated that the AQI of most cities improved to varying grades of quality during the COVID-19 pandemic; the city crowding levels altered post COVID-19 pandemic; and carbon dioxide releases from municipal vehicles in Canada have consecutively reduced. These were principally associated with a reduction in economic development and transportation limitations that cause a modification in energy use and a decrease in emissions (Filonchyk and Peterson, 2020). Another research by Dang and Trinh (2021) explained that the levels of $\mathrm{PM}_{2.5}$ and $\mathrm{NO}_{2}$ reduced by $4 \%$ and $5 \%$ on a universal level, respectively. They also found that reducing individual movements can help improve air quality. Cameletti (2020) reported that the MCO in the city 
of Brescia in Italy has definitely lowered the rate of road travel, thus reducing the most important emitted source related to $\mathrm{NO}_{2}$ and $\mathrm{PM}_{10}$ levels. According to the results, the reduction of air pollution and improvement of air quality may possibly decrease the mortality rate of COVID-19 and attenuate the spread of the infection (Fattorini \& Regoli, 2020; Wu et al., 2020b). Besides, there are several research studies that illustrate towns with higher outdoor air pollutants, such as $\mathrm{NO}_{2}$ level in Italy, Spain, France, and Germany (Ogen, 2020), $\mathrm{PM}_{2.5}$ level in USA (Wu et al., 2020a), and $\mathrm{PM}_{10}$ level in Kuwait (Achilleos et al., 2019), have had an upper mortality rate when affected by COVID-19. One study revealed a robust relationship between the level of $\mathrm{NO}_{2}$ and fatality of COVID19 (Ogen, 2020).

Another research by Briz-Redon et al. (2021) stated that the major and minor COVID-19 quarantines were not long sufficient to considerably improve the air quality regarding all the measured pollutants like $\mathrm{PM}_{10}, \mathrm{O}_{3}, \mathrm{CO}, \mathrm{SO}_{2}$, and $\mathrm{NO}_{2}$. Changes in air quality may be indirectly related to the quarantine due to various factors, such as the meteorological and their zonal or long-distance transport that are involved in the causes of these changes. In a study by Filonchyk and Peterson (2020), the diurnal levels of $\mathrm{PM}_{2.5}, \mathrm{PM}_{10}, \mathrm{SO}_{2}, \mathrm{NO}_{2}$, and $\mathrm{CO}$ were reported to decrease by $9 \%, 77 \%, 31.3 \%, 60.4 \%$, and $3 \%$, respectively, during the COVID-19 quarantine phase. The reason for reduction of $\mathrm{PM}$ and $\mathrm{NO}_{2}$ may be due to the reduced transport activities; whereas the reduction of $\mathrm{SO}_{2}$ and CO levels may be due to stationary sources. Another study by Wetchayont (2021) explained that $\mathrm{PM}_{2.5}, \mathrm{PM}_{10}$, and $\mathrm{O}_{3}$ reduced by $15.8 \%, 31.7 \%$, and $7.1 \%$, respectively during the quarantine phase. One study illustrated that concentrations of $\mathrm{PM}_{2.5}$ and $\mathrm{NO}_{2}$ reduced by $36 \%$ and $51 \%$, respectively, during the lockdown time (Zangari et al. 2020).

\section{Effects of Meteorological Items and COVID-19 Outbreak}

Recent research studies have shown the association between COVID-19 spread and temperature and humidity (Ma et al., 2020; Xie and Zhu, 2020). However, the possible effect of $\mathrm{PM}_{2.5}$ on COVID-19 is vague and it might be significant for decision makers and policy makers to take suitable measures to limit the increase of the COVID-19 transmission caused by aerosol diffusion (Chen et al., 2020). The climate is the most important parameter in determining the outbreak rate of COVID-19, for example, the mean temperature was considerably associated with COVID-19 (Tosepu et al., 2020). In a study, Elsaid and Ahmed (2021) noted that the increased temperature, wind speed, and overall increase in sunlight have been shown to be potential climatic parameters that gradually reduce the effects of the epidemic in Rio de Janeiro. One study reported that temperature (mean and minimum) and air quality were considerably related with the COVID-19 outbreak (Bashir et al., 2020). Another study by Dabisch et al. (2021) illustrated that an increase in temperature raises the decomposition rate of the contagious SARS-CoV-2 in aerosols. A study reported that the rate of virus inactivation in aerosol particles and droplets rises at middle relative humidity (RH), e.g., 40-60\%, as compared to other moisture levels (Lin and Marr, 2019). Some studies say that COVID-19 deactivation is best at around $50-80^{\circ} \mathrm{C}$ and $40-50 \%$ relative humidity (Rezaei et al., 2020). Latif et al. (2021) demonstrated that the effect of rainfall, relative humidity, temperature, and sunlight can be regarded as minimal under the COVID-19 lockdown compared to the same parameters recorded in the previous years. Besides, meteorological factors affect the occurrence and intensity of SARS-COV-2 disease (Cacho et al., 2020). Moreover, in polluted cities with low wind speed, the accelerated transmission of viral infection is due to air pollution-to-person transmission rather than person-toperson transmission (Coccia, 2020).

One study reported that the mean value of $\mathrm{O}_{3}$ and $\mathrm{NO}_{2}$ showed raised levels in winter and low levels in summer (Hoque et al., 2020). Further pressures appear to have a positive impact on the type of pollution. Particulate matter cannot diffuse suitably and tends to accumulate, leading to high loads of atmospheric particles (Czerwińska and Wielgosiński, 2020). Briz-Redón et al. (2021) found no evidence related to the decrease in COVID-19 incidences at warmer average, lowest and highest temperatures. However, non-climatic factors like the density of population, people by age, quantity of passengers and number of firms were taken into account in the analysis, and the obtained results need to be interpreted cautiously (Briz-Redón and Serrano-Aroca, 2020). In sum, it is impossible that air temperature and optimal $\mathrm{RH}$ combinations for virus inactivation be far from those typical for human comfort. Another study showed that the air temperature and wind direction are related to a considerable reduction in the level of $\mathrm{PM}_{10}$ and $\mathrm{PM}_{2.5}$. On the contrary, relative air humidity was most strongly negatively correlated with the concentration of particulate matter (Radzka, 2020). Under a high-speed wind situation, respiratory droplets may convert to very small respiratory droplets in the wind direction. In this situation, the risk of SARS-CoV-2 transmission increases (Nazari et al., 2021). One study stated that the humidity, wind speed, and sunlight have an indirect relationship with the outbreak rate (Ahmadi et al., 2020). Therefore, the influence of meteorological conditions cannot be ignored and further research must be conducted in the future.

\section{Indoor Air Pollutants During the COVID-19 Pandemic}

One of the major origins of particulate matter in dwelling houses is the kitchen as a food preparation area emitting steam, smoke, and aerosols (Tan et al., 2013). Due to the possibility of gas-reentrance via the infiltration air flow, smoke and effluents can be released indoor through indirect paths if there is a lack of a suitable extraction system space. Another huge contributor, which is on rise in houses now, is the application of cleaning products and disinfectants (Quang et al., 2013), as well as cosmetic and individual health factors (fresheners, hair sprays, etc.) (Sangiorgi et al., 2013). Before COVID-19, people spent less than $60 \%$ of their diurnal time indoors, while they now are staying at home $100 \%$ of the time on a prolonged basis (Domínguez-Amarillo et al., 2020). Although the city's outdoor air pollution was reduced during quarantine, the public's contact with indoor pollutants (e.g. $\mathrm{PM}_{2.5}$, VOCs, $\mathrm{CO}_{2}$, and $\mathrm{NO}_{2}$, etc.) was commonly further transitory and continuous. There are many research studies relevant to indoor air pollution and COVID-19 (DomínguezAmarillo et al., 2020; Nwanaji-Enwerem et al., 2020). One 
study reported that the $\mathrm{CO}_{2}$ level did not exceed $1000 \mathrm{mg} / \mathrm{l}$ in indoor air buildings (Ahlawat et al., 2020).

Indoor air quality means the air purity in and around buildings and facilities is specifically in relation to the health and comfort of building residents. Inadequate ventilation can lead to a rise in the levels of pollutants carrying the coronavirus in restricted places by not feeding enough outside air to further attenuate these pollutants and not removing the indoor air pollutants outside the ventilated region. Temperature and humidity are among the parameters affecting the reduction or increase of the spread of the coronavirus (Elsaid and Ahmed, 2021). Research on the indoor air quality in houses under COVID-19 quarantine is also restricted and most research addresses the home sanitizer agents as specifically related to the origin of indoor pollution. Indoor environment vulnerabilities, including domestic comfort and work accomplishment-indoor air quality (IAQ) are often perceived as more acceptable at low $\mathrm{RH}$ and low temperature, depending on changes not only of the VOC emission profile, but also of the dynamics, composition, deposition and re-suspension of inhaled (Spena et al., 2020). The meteorological situation may also play an important role in air pollution-virus interactions. Although, a recent study did not find any evidence of an association between solar UV radiation and COVID-19, air pollution, particularly PM, can reduce UV penetration, as illustrated by various research studies, which explained that air pollutants, such as PM considerably reduced vitamin D synthesis (Bourdrel et al., 2021). Current research explains that microbial community composition and level are considerably affected by particle concentration and dimension (Comunian et al. 2020).

Moreover, the level and infectivity of smaller airborne particles reduce more slowly, and thus their longer residence time in the air emphasizes the concern that they pose. Both are applicable to SARS-CoV-2, which has a size in the order of 20nm (Spena et al., 2020). Current research in the United States and Italy has reported that COVID-19 can remain in aerosols for more than $3 \mathrm{~h}$ and diffuse in long distances through the particles in the air (Jia et al., 2021).

\section{CONCLUSIONS}

The results of this review study revealed the significance of the relationship between air pollutants $\mathrm{PM}_{2.5}, \mathrm{PM}_{10}, \mathrm{SO}_{2}, \mathrm{NO}_{2}$, $\mathrm{CO}$, and $\mathrm{O}_{3}$, and COVID-19 phenomenon. Twenty-four precise evaluations indicated that the AQI in most countries improved to varying grades during the COVID-19 pandemic. Indoor pollutant concentrations were normally higher than outdoor pollutant concentrations during the COVID-19 lockdown. There is a relationship between meteorological items (rainfall, $\mathrm{RH}$, temperature, wind direction, wind speed, and sunlight) and the COVID-19 spread. The effects of temperature and $\mathrm{RH}$ on COVID-19 spread are of great interest among meteorological factors. According to the findings of this study, if confirmed by future studies, air quality should also be considered as part of an integrated approach toward sustainable development, human health protection, and prevention of epidemic spreads. Considering the potential transmission paths of COVID-19, social and physical distancing, personal protective equipment, and environmental disinfection are currently effective ways to slow down the transmission of COVID-19, and environmental pollution control can enhance people's overall capability to oppose respiratory infections.

There is a tight linkage between economics and environmental pollution. The reeducation of economic action and traffic limitations openly affected the modification of energy consumption in countries and effectively decreased environmental pollution. Based on the WHO, about $90 \%$ of the world's population are exposed to air pollution levels, which put them at increased risks for serious cardiorespiratory diseases, including cancer. Most studies demonstrate that both long-term and short-term exposures to high concentrations of pollutants are associated with an increase in COVID-19 transmission globally. It is crucial that policy makers and decision makers adopt more valuable methods to assist betterment of air pollution, particularly in developing nations, or control contact with pollutants so as to preserve public wellbeing. Seven recommendations for air quality improvement are as follows:

1. The scientists are suggested to conduct further research considering the association between the indoor air quality and COVID-19 outbreak in the future.

2. Further research is required to acquire comprehensive awareness of aerosol diffusion of COVID-19 so that more validated and useful procedures can be used to prevent the pandemic.

3. It should be stated that other factors, e.g., climate conditions, vehicles congestion, industrial actions, and fuel combustion must be well thought out.

4. The inactivation time of coronavirus in the air under various environmental conditions, such as temperature, $\mathrm{RH}$, solar radiation, wind speed, etc., as well as the inactivation time of coronavirus on various types of surfaces should be fully investigated.

5. Air quality should be considered as a component of an integrated method that is helpful for sustainable development, human health protection, and control of pandemics.

6. The $\mathrm{CO}_{2}$ monitors should be used in indoor buildings like health care centers, hospitals, nursing homes, schools, restaurants, dormitories, and universities.

7. Methods to decrease air pollution at the origin must be established and should be used in all industries and power plants.

Author notes: The author read and approved the final manuscript.

Funding: No external funding is received for this article.

Acknowledgements: The author would like to appreciate Shahrekord University of Medical Sciences.

Declaration of interest: The author declares that he has no competing interests.

Ethics approval and consent to participate: Not applicable.

Availability of data and materials: All data generated or analyzed during this study are available for sharing when appropriate request is directed to corresponding author. 


\section{REFERENCES}

Abdullah, S., Abu Mansor, A., Mohd Napi, N. N. L., Wan Mansor, W. N., Ahmed, A. N., Ismail, M. and Ramly, Z. T. A. (2020). Air quality status during 2020 Malaysia Movement Control Order (MCO) due to 2019 novel coronavirus (2019-nCoV) pandemic. Science of the Total Environment, 729, 139022. https://doi.org/10.1016/ j.scitotenv.2020.139022

Achilleos, S., Al-Ozairic, E., Alahmad, B., Garshick, E., Neophytou, A. M., Bouhamra, W., Yassin, M. F. and Koutrakis, P. (2019). Acute effects of air pollution on mortality: A 17-year analysis in Kuwait. Environment International, 126, 476-483. https://doi.org/10.1016/ j.envint.2019.01.072

Ahlawat, A., Mishra, S. K., Birks, J. W., Costabile, F. and Wiedensohler, A. (2020). Preventing airborne transmission of SARS-CoV-2 in hospitals and nursing homes. International Journal of Environmental Research and Public Health, 17(22), 8553. https://doi.org/10.3390/ ijerph17228553

Ahmadi, D. and Fadaei, A. (2021). Efficiency evaluation of hospitals sterilization by biological and chemical methods. Quality of Life, 20(1-2), 23-30. https://doi.org/10.7251/ QOL2101023A

Ahmadi, M., Sharifi, A., Dorosti, S., Ghoushchi, S. J. and Ghanbari, N. (2020). Investigation of effective climatology parameters on COVID-19 outbreak in Iran. Science of the Total Environment, 729, 138705. https://doi.org/10.1016/ j.scitotenv.2020.138705

Ash'aari, Z. H., Aris, A. Z., Ezani, E., Kamal, N. I. A., Jaafar, N., Jahaya, J. N., Abdul Manan, S. and Umar Saifuddin, M. F. (2020). Spatiotemporal variations and contributing factors of air pollutant concentrations in Malaysia during movement control order due to pandemic COVID-19. Aerosol and Air Quality Research, 20(10), 2047-2061. https://doi.org/10.4209/aaqr.2020.06.0334

Bao, R. and Zhang, A. (2020). Does lockdown reduce air pollution? Evidence from 44 cities in northern China. Science of the Total Environment, 731, 139052. https://doi.org/10.1016/j.scitotenv.2020.139052

Bashir, M. F., Ma, B., Komal, B., Bashir, M. A., Tan, D. and Bashir, M. (2020). Correlation between climate indicators and COVID-19 pandemic in New York, USA. Science of the Total Environment, 728, 138835. https://doi.org/10.1016/ j.scitotenv.2020.138835

Bourdrel, T., Annesi-Maesano, I., Alahmad, B., Maesano, C. N. and Bind, M.-A. (2021). The impact of outdoor air pollution on COVID-19: A review of evidence from in vitro, animal, and human studies. European Respiratory Review, 30(159), 200242. https://doi.org/10.1183/16000617.0242-2020

Brandt, E. B., Beck, A. F. and Mersha, T. B. (2020). Air pollution, racial disparities, and COVID-19 mortality. Journal of Allergy and Clinical Immunology, 146(1), 61-63. https://doi.org/10.1016/j.jaci.2020.04.035
Briz-Redón, Á. and Serrano-Aroca, Á. (2020). A spatiotemporal analysis for exploring the effect of temperature on COVID-19 early evolution in Spain. Science of the Total Environment, 728, 138811. https://doi.org/10.1016/ j.scitotenv.2020.138811

Briz-Redón, Á., Belenguer-Sapiña, C. and Serrano-Aroca, Á. (2021). Changes in air pollution during COVID-19 lockdown in Spain: A multi-city study. Journal of Environmental Sciences, 101, 16-26. https://doi.org/ 10.1016/j.jes.2020.07.029

Cacho, P. M., Hernández, J. L., López-Hoyos, M. and MartínezTaboada, V. M. (2020). Can climatic factors explain the differences in COVID-19 incidence and severity across the Spanish regions? An ecological study. Environmental Health, 19(1), 1-8. https://doi.org/10.1186/s12940-02000660-4

Cameletti, M. (2020). The effect of corona virus lockdown on air pollution: Evidence from the City of Brescia in Lombardia Region (Italy). Atmospheric Environment, 239, 117794. https://doi.org/10.1016/j.atmosenv.2020.117794

Chen, Q.-X., Huang, C.-L., Yuan, Y. and Tan, H.-P. (2020). Influence of COVID-19 event on air quality and their association in Mainland China. Aerosol and Air Quality Research, 20(7), 1541-1551. https://doi.org/10.4209/ aaqr.2020.05.0224

Chirico, F., Sacco, A., Bragazzi, N. L. and Magnavita, N. (2020). Can air-conditioning systems contribute to the spread of SARS/MERS/COVID-19 infection? Insights from a rapid review of the literature. International Journal of Environmental Research and Public Health, 17(17), 6052. https://doi.org/10.3390/ijerph17176052

Coccia, M. (2020). Factors determining the diffusion of COVID-19 and suggested strategy to prevent future accelerated viral infectivity similar to COVID. Science of the Total Environment, 729, 138474. https://doi.org/10.1016/ j.scitotenv.2020.138474

Coccia, M. (2021). How do low wind speeds and high levels of air pollution support the spread of COVID-19? Atmospheric Pollution Research, 12(1), 437-445. https://doi.org/10.1016/ j.apr.2020.10.002

Cole, M. A., Elliott, R. J. and Liu, B. (2020). The impact of the Wuhan Covid-19 lockdown on air pollution and health: A machine learning and augmented synthetic control approach. Environmental and Resource Economics, 76(4), 553-580. https://doi.org/10.1007/s10640-020-00483-4

Collivignarelli, M. C., Abbà, A., Bertanza, G., Pedrazzani, R., Ricciardi, P. and Miino, M.C. (2020). Lockdown for CoViD2019 in Milan: What are the effects on air quality? Science of the Total Environment, 732, 139280. https://doi.org/ 10.1016/j.scitotenv.2020.139280

Comunian, S., Dongo, D., Milani, C. and Palestini, P. (2020). Air pollution and COVID-19: The role of particulate matter in the spread and increase of COVID-19's morbidity and mortality. International Journal of Environmental Research and Public Health, 17(12), 4487. https://doi.org/10.3390/ ijerph17124487 
Conticini, E., Frediani, B. and Caro, D. (2020). Can atmospheric pollution be considered a co-factor in extremely high level of SARS-CoV-2 lethality in Northern Italy? Environmental Pollution, 261, 114465. https://doi.org/10.1016/j.envpol. 2020.114465

Correia, G., Rodrigues, L., Da Silva, M. G. and Gonçalves, T. (2020). Airborne route and bad use of ventilation systems as non-negligible factors in SARS-CoV-2 transmission. Medical Hypotheses, 141, 109781. https://doi.org/10.1016/ j.mehy.2020.109781

Czerwińska, J. and Wielgosiński, G. (2020). The effect of selected meteorological factors on the process of "Polish smog” formation. Journal of Ecological Engineering, 21(1), 180-187. https://doi.org/10.12911/22998993/112764

Dabisch, P., Schuit, M., Herzog, A., Beck, K., Wood, S., Krause, M., Miller, D., Weaver, W., Freeburger, D., Hooper, I., Green, B., Williams, G., Holland, B., Bohannon, J., Wahl, V., Yolitz, J., Hevey, M. and Ratnesar-Shumate, S. (2021). The influence of temperature, humidity, and simulated sunlight on the infectivity of SARS-CoV-2 in aerosols. Aerosol Science and Technology, 55(2), 142-153. https://doi.org/10.1080/02786826.2020.1829536

Dang, H.-A. H. and Trinh, T.-A. (2021). Does the COVID-19 lockdown improve global air quality? New cross-national evidence on its unintended consequences. Journal of Environmental Economics and Management, 105, 102401. https://doi.org/10.1016/j.jeem.2020.102401

Dantas, G., Siciliano, B., França, B. B., da Silva, C. M. and Arbilla, G. (2020). The impact of COVID-19 partial lockdown on the air quality of the city of Rio de Janeiro, Brazil. Science of the Total Environment, 729, 139085. https://doi.org/10.1016/j.scitotenv.2020.139085

Domínguez-Amarillo, S., Fernández-Agüera, J., CesterosGarcía, S. and González-Lezcano, R. A. (2020). Bad air can also kill: Residential indoor air quality and pollutant exposure risk during the COVID-19 crisis. International Journal of Environmental Research and Public Health, 17(19), 7183. https://doi.org/10.3390/ijerph17197183

Dong, R., Fisman, R., Wang, Y. and Xu, N. (2019). Air pollution, affect, and forecasting bias: Evidence from Chinese financial analysts. Journal of Financial Economics, 139(3), 971-984. https://doi.org/10.1016/j.jfineco.2019.12.004

Elsaid, A. M. and Ahmed, M. S. (2021). Indoor air quality strategies for air-conditioning and ventilation systems with the spread of the global coronavirus (COVID-19) epidemic: Improvements and recommendations. Environmental Research, 111314. https://doi.org/10.1016/ j.envres.2021.111314

Farhadi, Z., Gorgi, H. A., Shabaninejad, H., Delavar, M. A. and Torani, S. (2020). Association between $\mathrm{PM}_{2.5}$ and risk of hospitalization for myocardial infarction: A systematic review and a meta-analysis. BMC Public Health, 20(1), 314. https://doi.org/10.1186/s12889-020-8262-3

Fattorini, D. and Regoli, F. (2020). Role of the chronic air pollution levels in the Covid-19 outbreak risk in Italy. Environmental Pollution, 264, 114732. https://doi.org/ 10.1016/j.envpol.2020.114732
Fernández-Agüera, J., Domínguez-Amarillo, S., Sendra, J. J., Suárez, R. and Oteiza, I. (2019). Social housing airtightness in Southern Europe. Energy and Buildings, 183, 377-391. https://doi.org/10.1016/j.enbuild.2018.10.041

Filonchyk, M. and Peterson, M. (2020). Air quality changes in Shanghai, China, and the surrounding urban agglomeration during the COVID-19 lockdown. Journal of Geovisualization and Spatial Analysis, 4(2), 1-7. https://doi.org/10.1007/s41651-020-00064-5

Gan, W. Q., Davies, H. W., Koehoorn, M. and Brauer, M. (2012). Association of long-term exposure to community noise and traffic-related air pollution with coronary heart disease mortality. American Journal of Epidemiology, 175(9), 898906. https://doi.org/10.1093/aje/kwr424

He, G., Pan, Y. and Tanaka, T. (2020). The short-term impacts of COVID-19 lockdown on urban air pollution in China. Nature Sustainability, 3(12),1005-1011. https://doi.org/ 10.1038/s41893-020-0581-y

Hoque, M., Ashraf, Z., Kabir, H., Sarker, E. and Nasrin, S. (2020). Meteorological influences on seasonal variations of air pollutants $\left(\mathrm{SO}_{2}, \mathrm{NO}_{2}, \mathrm{O}_{3}, \mathrm{CO}, \mathrm{PM}_{2.5}\right.$ and $\left.\mathrm{PM}_{10}\right)$ in the Dhaka Megacity. American Journal of Pure and Applied Biosciences, 2, 15-23. https://doi.org/10.34104/ajpab.020. 15023

Hou, K. and Xu, X. (2022). Evaluation of the influence between local meteorology and air quality in Beijing using generalized additive models. Atmosphere, 13(1), 24. https://doi.org/10.3390/atmos13010024

Ito, K. and Zhang, S. (2020). Willingness to pay for clean air: Evidence from air purifier markets in China. Journal of Political Economy, 128(5), 1627-1672. https://doi.org/10. 1086/705554

Jia, B., Liu, S. and Ng, M (2021). Air quality and key variables in high-density housing. Sustainability, 13(8), 4281. https://doi.org/10.3390/su13084281

Kanniah, K. D., Zaman, N. A. F. K., Kaskaoutis, D. G. and Latif, M. T. (2020). COVID-19's impact on the atmospheric environment in the Southeast Asia region. Science of the Total Environment, 736, 139658. https://doi.org/10.1016/ j.scitotenv.2020.139658

Latif, M. T., Dominick, D., Hawari, N. S. S. L., Mohtar, A. A. A. and Othman, M. (2021). The concentration of major air pollutants during the movement control order due to the COVID-19 pandemic in the Klang Valley, Malaysia. Sustainable Cities and Society, 66, 102660. https://doi.org/ 10.1016/j.scs.2020.102660

Li, H., Liu, S.-M., Yu, X.-H., Tang, S.-L. and Tang, C.-K. (2020). Coronavirus disease 2019 (COVID-19): Current status and future perspectives. International Journal of Antimicrobial Agents, 55(5), 105951. https://doi.org/10.1016/ j.ijantimicag.2020.105951

Li, J. and Tartarini, F. (2020). Changes in air quality during the COVID-19 lockdown in Singapore and associations with human mobility trends. Aerosol and Air Quality Research 20(8), 1748-1758. https://doi.org/10.4209/aaqr.2020.06. 0303 
Lin, K. and Marr, L. C. (2019). Humidity-dependent decay of viruses, but not bacteria, in aerosols and droplets follows disinfection kinetics. Environmental Science \& Technology, 54(2), 1024-1032. https://doi.org/10.1021/acs.est.9b04959

Lokhandwala, S. and Gautam, P. (2020). Indirect impact of COVID-19 on environment: A brief study in Indian context. Environmental Research, 188, 109807. https://doi.org/ 10.1016/j.envres.2020.109807

Ma, Y., Zhao, Y., Liu, J., He, X., Wang, B., Fu, S., Yan, J., Niu, J., Zhou, J. and Luo, B. (2020). Effects of temperature variation and humidity on the death of COVID-19 in Wuhan, China. Science of the Total Environment, 724, 138226. https://doi.org/10.1016/j.scitotenv.2020.138226

Mahato, S., Pal, S. and Ghosh, K. G. (2020). Effect of lockdown amid COVID-19 pandemic on air quality of the megacity Delhi, India. Science of the Total Environment, 730, 139086. https://doi.org/10.1016/j.scitotenv.2020.139086

Moher, D., Liberati, A., Tetzlaff, J. and Altman, D. G. (2010). Preferred reporting items for systematic reviews and metaanalyses: The PRISMA statement. International Journal of Surgery, 8(5), 336-341. https://doi.org/10.1016/j.ijsu.2010. 02.007

Navinya, C., Patidar, G. and Phuleria, H. C. (2020). Examining effects of the COVID-19 national lockdown on ambient air quality across urban India. Aerosol and Air Quality Research, 20(8), 1759-1771. https://doi.org/10.4209/ aaqr.2020.05.0256

Nazari, A., Jafari, M., Rezaei, N., Arash-Azad, S., Talati, F., Nejad-Rahim, R., Taghizadeh-Hesary, F. and TaghizadehHesary, F. (2021). Effects of high-speed wind, humidity, and temperature on the generation of a SARS-CoV-2 aerosol; a novel point of view. Aerosol and Air Quality Research, 21, 200574-200574. https://doi.org/10.4209/ aaqr.200574

Nwanaji-Enwerem, J. C., Allen, J. G. and Beamer, P. I. (2020). Another invisible enemy indoors: COVID-19, human health, the home, and United States indoor air policy. Journal of Exposure Science \& Environmental Epidemiology, 30(5), 773-775. https://doi.org/10.1038/s41370-020-0247$\mathrm{X}$

Ogen, Y. (2020). Assessing nitrogen dioxide $\left(\mathrm{NO}_{2}\right)$ levels as a contributing factor to coronavirus (COVID-19) fatality. Science of the Total Environment, 726, 138605. https://doi.org/10.1016/j.scitotenv.2020.139239

Quang, T. N., He, C., Morawska, L. and Knibbs, L. D. (2013). Influence of ventilation and filtration on indoor particle concentrations in urban office buildings. Atmospheric Environment, 79, 41-52. https://doi.org/10.1016/ j.atmosenv.2013.06.009

Radzka, E. (2020). The effect of meteorological conditions on air pollution in Siedlce. Journal of Ecological Engineering, 21(1), 97-104. https://doi.org/10.12911/22998993/113074

Rezaei, N., Jafari, M., Nazari, A., Salehi, S., Talati, F., Torab, R. and Nejad-Rahim, R. (2020). A novel methodology and new concept of SARS-CoV-2 elimination in heating and ventilating air conditioning systems using waste heat recovery. AIP Advances, 10(8), 085308. https://doi.org/ $10.1063 / 5.0021575$
Rosario, D. K., Mutz, Y. S., Bernardes, P. C. and Conte-Junior, C. A. (2020). Relationship between COVID-19 and weather: Case study in a tropical country. International Journal of Hygiene and Environmental Health, 229, 113587. https://doi.org/10.1016/j.ijheh.2020.113587

Sadeghi, M., Fadaei, A. and Ataee, M. (2020). Assessment of hospitals medical waste management in Chaharmahal and Bakhtiari Province in Iran. Archives of Agriculture and Environmental Science, 5(2), 157-163. https://doi.org/ 10.26832/24566632.2020.0502011

Sangiorgi, G., Ferrero, L., Ferrini, B. S., Lo Porto, C., Perrone, M. G., Zangrando, R., Gambaro, A., Lazzati, Z. and Bolzacchini, E. (2013). Indoor airborne particle sources and semi-volatile partitioning effect of outdoor fine PM in offices. Atmospheric Environment, 65, 205-214. https://doi.org/10.1016/j.atmosenv.2012.10.050

Shin, S., Bai, L., Oiamo, T. H., Burnett, R. T., Weichenthal, S., Jerrett, M., Kwong, J. C., Goldberg, M. S., Copes, R., Kopp, A. and Chen, H. (2020). Association between road traffic noise and incidence of diabetes mellitus and hypertension in Toronto, Canada: A population-based cohort study. Journal of the American Heart Association, 9(6), e013021. https://doi.org/10.1161/JAHA.119.013021

Song, Y., Li, Z., Liu, J., Yang, T., Zhang, M. and Pang, J. (2021). The effect of environmental regulation on air quality in China: A natural experiment during the COVID-19 pandemic. Atmospheric Pollution Research, 12(4), 21-30. https://doi.org/10.1016/j.apr.2021.02.010

Spena, A., Palombi, L., Corcione, M., Carestia, M. and Spena, V. A. (2020). On the optimal indoor air conditions for SARS-CoV-2 inactivation. An enthalpy-based approach. International Journal of Environmental Research and Public Health, 17(17), 6083. https://doi.org/10.3390/ ijerph17176083

Tan, C. C., Finney, K. N., Chen, Q., Russell, N. V., Sharifi, V. N. and Swithenbank, J. (2013). Experimental investigation of indoor air pollutants in residential buildings. Indoor and Built Environment, 22(3), 471-489. https://doi.org/10.1177/ $1420326 X 12441806$

Tian, X., An, C., Chen, Z. and Tian, Z. (2021). Assessing the impact of COVID-19 pandemic on urban transportation and air quality in Canada. Science of The Total Environment, 765, 144270. https://doi.org/10.1016/j.scitotenv.2020. 144270

Tobías, A., Carnerero, C., Reche, C., Massagué, J., Via, M., Minguillón, M. C., Alastuey, A. and Querol, X. (2020). Changes in air quality during the lockdown in Barcelona (Spain) one month into the SARS-CoV-2 epidemic. Science of the Total Environment, 726, 138540. https://doi.org/10. 1016/j.scitotenv.2020.138540

Tosepu, R., Gunawan, J., Effendy, D. S., Lestari, H., Bahar, H. and Asfian, P. (2020). Correlation between weather and Covid-19 pandemic in Jakarta, Indonesia. Science of The Total Environment, 725, 138436. https://doi.org/10.1016/ j.scitotenv.2020.138436 
Wang, J., Xu, X., Wang, S., He, S. and He, P. (2021). Heterogeneous effects of COVID-19 lockdown measures on air quality in Northern China. Applied Energy, 282, 116179. https://doi.org/10.1016/j.apenergy.2020.116179

Wetchayont, P. (2021). Investigation on the impacts of COVID-19 lockdown and influencing factors on air quality in Ggreater Bangkok, Thailand. Advances in Meteorology, 2021, 6697707. https://doi.org/10.1155/2021/6697707

Wu, X., Nethery, R. C., Sabath, B. M., Braun, D. and Dominici, F. (2020a). Exposure to air pollution and COVID-19 mortality in the United States. MedRxiv. https:/doi.org/ 10.1101/2020.04.05.20054502
Wu, X., Nethery, R. C., Sabath, M., Braun, D. and Dominici, F. (2020b). Air pollution and COVID-19 mortality in the United States: Strengths and limitations of an ecological regression analysis. Science Advances, 6(45), eabd4049. https://doi.org/10.1126/sciadv.abd4049

Xie, J. and Zhu, Y. (2020). Association between ambient temperature and COVID-19 infection in 122 cities from China. Science of the Total Environment, 724, 138201. https://doi.org/10.1016/j.scitotenv.2020.138201

Zangari, S., Hill, D. T., Charette, A. T. and Mirowsky, J. E. (2020). Air quality changes in New York City during the COVID-19 pandemic. Science of the Total Environment, 742, 140496. https://doi.org/10.1016/j.scitotenv.2020.140496 